\title{
EFFECTIVENESS OF ONLINE LEARNING USING MADRASAH E-LEARNING IN THE PANDEMIC COVID-19
}

\section{EFEKTIVITAS PEMBELAJ ARAN DARING MENGGUNAKAN E-LEARNING MADRASAH DI MASA COVID-19}

\author{
Ririn Eva Hidayati \\ M AN 1 Kota M alang, Kementerian Agama, Kota M alang-Indonesia \\ E-mail: ririneva@gmail.com
}

\begin{abstract}
This research was conducted to see the effectiveness of the implementation of online learning using madrasah e-learning and to find out the inhibiting and supporting factors of using e-learning applications as a learning medium. This research is a descriptive qualitative. The data were obtained by distributing questionnaires in google form which contained closed, semi-closed, and open questions, then the data were analyzed descriptively. Respondents of this research are students and teachers of MAN 1 Kota Malang who carried out learning using e-learning applications. The results of the observation informed that $80 \%$ of respondents claimed to be able to access and use madrasah e-learning. Online learning innovations using madrasah e-learning helped students undergo learning during the pandemic. The implementation of online learning using madrasah e-learning was quite effective, which can be seen from $78 \%$ of students who can achieve the minimum completeness criteria even there was ineffectiveness in the evaluation process. Teacher professionalism was needed in online learning using madrasah e-learning in order to create fun and meaningful learning. Improving the application was also still needed to make madrasah e-learning easier to use (user-friendly). The obstacles in online learning can be overcome by the collaboration between madrasah, parents, teachers, and students.
\end{abstract}

Keywords: effectiveness, online learning, madrasah e-learning, covid-19 pandemic

\section{ABSTRAK}

Penelitian ini dilakukan untuk mengetahui efektifitas pelaksanaan pembelajaran daring menggunakan e-learning madrasah dan menentukan faktor penghambat dan pendukung penggunaan aplikasi e-learning sebagai media pembelajaran. Penelitian ini bersifat dekriptif kualitiatif. Data didapatkan melalui penyebaran kuisioner dalam bentuk google form yang berisi pertanyaan tertutup, semi tertutup dan terbuka, kemudian data dianalisis secara deskriptif. Responden penelitian ini adalah siswa dan guru MAN 1 Kota Malang yang melaksanakan pembelajaran memanfaatkan aplikasi e-learning. Hasil observasi menginformasikan $80 \%$ responden mengaku dapat mengakses dan menggunakan e-learning madrasah. Inovasi pemanfaatan e-learning madrasah dalam pembelajaran daring membantu siswa menjalani pembelajaran selama masa pandemi. Pelaksanaan pemanfaatan e-learning madrasah dalam pembelajaan daring berlangsung cukup efektif, yang terlihat dari $78 \%$ siswa dapat mencapai kriteria ketuntasan minimal (KKM), walau ada ketidakefektifan dalam proses evaluasi. Profesionalitas guru sangat dibutuhkan saat memanfaatkan e-learning madrasah dalam pembelajaran daring agar menghasilkan pembelajaran yang menyenangkan dan bermakna. Penyempurnaan aplikasi juga masih diperlukan agar elearning madrasah lebih mudah dipergunakan (user-friendly). Kendala yang dihadapi selama pembelajaran daring dapat diatasi dengan adanya kerjasama antara madrasah, orang tua, guru dan siswa.

Kata Kunci: efektivitas, pembelajaran daring, e-learning madrasah, covid-19, pandemi 


\section{PENDAHULUAN}

\section{A. Latar Belakang}

Sejak permulaan tahun 2020 hingga saat ini, corona menjadi sentral pembicaraan yang cukup trending. Virus corona merupakan adalah salah satu virus yang mengerikan karena dapat menimbulkan kematian. Jumlah korban virus ini tercatat dengan angka yang cukup besar. Pandemi Covid-19 yang terjadi di dunia mempengaruhi segala bidang kehidupan tak terkecuali sektor pendidikan. Berbagai upaya telah dilakukan untuk mengendalikan penyebaran virus ini, salah satunya dengan memberlakukan Pembatasan Sosial Berskala Besar (PSBB). Menteri Pendidikan mendukung program PSBB dengan memberlakukan Surat Edaran Nomor 4 Tahun 2020. Melalui surat edaran itu Menteri Pendidikan mewartakan bahwa proses pembelajaran dilangsungkan dari rumah (Khusniyah, 2020).

Hal senada juga dilakukan oleh Menteri Agama dengan memberlakukan Surat Keputusan Nomor 2791/2020 tentang Tindakan Pencegahan Penyebaran Virus Corona Disease-19 (Covid-19) di lingkungan Kementerian Agama. Melalui Surat Keputusan ini Menteri Agama berpesan agar seluruh kegiatan pembelajaran di madrasah diselenggarakan secara daring.

Pembelajaran daring merupakan langkah strategis dalam mencegah penularan wabah Covid-19 di dunia pendidikan. Hal ini dikarenakan inti pembelajaran daring ialah dilaksanakan tanpa bertemu secara langsung. Akhir-akhir ini banyak lembaga pendidikan yang menggunakan teknologi dan menerapkan sistem pembelajaran daring untuk mendukung kegiatan pembelajaran. Hal ini menuntut guru untuk mendesain ulang strategi pembelajarannya. Guru harus menyiapkan rencana pembelajaran yang memfasilitasi siswa untuk belajar dari rumah. Pemilihan strategi pembelajaran yang tepat disertai suri tauladan dan akhlak yang mulia guru dalam melaksanakan proses pembelajaran sangat diperlukan dalam menyukseskan program belajar dari rumah (BDR). Hal ini dikerjakan guna memudahkan siswa melakukan pembelajaran di masa pandemi ini (Kurniasari, 2020).

Dukungan Kementerian Agama dalam pelaksanaan pembelajaran daring adalah dengan menyediakan platform belajar daring yang dinamai dengan e-learning madrasah. Di awal tahun 2020 Direktorat KSMM Madrasah mencetuskan gagasan pembuatan platform pembelajaran digital yang dapat digunakan untuk menunjang proses pembelajaran di madrasah. Dalam perkembangannya e-learning madrasah telah menjalani berkali-kali proses perbaikan untuk memperbanyak dan membenahi fitur-fitur yang ada. Aplikasi ini terdiri dari berbagai fitur yang mendukung siswa dan guru dalam kegiatan pembelajaran. Fitur yang terdapat dalam e-learning didesain dapat membantu mereka memperoleh informasi, tugas serta pembelajaran secara cepat. Fitur tersebut adalah forum madrasah, kelas online, kalender dan komunikasi. Fitur Kelas Online terdiri dari beragam konten. Diantaranya adalah standar kompetensi (KI/KD), kriteria ketuntasan minimal, rencana pembelajaran, bahan ajar, absensi kelas, jurnal guru, computer based test $(C B T)$, penilaian pengetahuan $(\mathrm{KI} 3)$, penilaian keterampilan (KI4), penilaian akhir semester, rekap nilai rapor, monitoring aktivitas siswa, kalender kelas dan pengaturan kelas.

Aplikasi e-learning madrasah diinginkan bisa dipergunakan oleh semua madrasah untuk mendukung proses pembelajaran yang lebih interaktif, terstruktur, dan menawan sehingga didambakan dapat memotivasi madrasah mampu membuat pembaharuan di bidang teknologi informasi. Seluruh pengguna e-learning di madrasah tersebut akan mempunyai user-name sendiri untuk bisa masuk dan mengakses aplikasi e-learning Madrasah, kapanpun dan dimanapun. Dalam versi 2.0.0 e-learning madrasah juga ditambahkan fitur video conference yang memfasilitasi guru dan siswa melaksanakan pembelajaran tatap muka secara daring sehingga terjadi komunikasi dua arah.

Pembelajaran daring menggunakan e-learning memiliki beberapa keunggulan dan kekurangan. Keunggulan pembelajaran daring adalah menciptakan suasana belajar baru, memberikan fleksibilitas tempat dan waktu, waktu berkumpul dengan keluarga lebih banyak, mengurangi pengeluaran uang transport, lebih bertanggung 
jawab, kreatif, dan mandiri (Oktavian dan Aldya, 2020). Selain itu, dapat disesuaikan dengan gaya belajar siswa.

Kekurangan pembelajaran daring yaitu susah membuat siswa fokus karena keadaan rumah kurang mendukung untuk proses pembelajaran daring. Lebih dari itu, pembelajaran daring menyebabkan minimnya interaksi antara guru dan siswa dan antar siswa, pemberian tugas yang berlebihan, dipengaruhi koneksi internet, lebih boros kuota internet, dan lebih sulit memahami dan menguasai materi pelajaran (Fitrah dan Ruslan, 2021).

Dengan segala kelebihan dan kekurangan pembelajaran daring dengan menggunakan aplikasi e-learning madrasah perlu dikaji efektivitas pembelajaran daring menggunakan e-learning madrasah di masa pandemi covid 19.

\section{B. Rumusan Masalah}

Berdasarkan pada latar belakang penelitian, rumusan masalah penelitian ini adalah:

1. Bagaimana efektifitas pelaksanaan pembelajaran daring menggunakan e-learning madrasah?

2. Faktor-faktor apa yang dapat menghambat dan mendukung penggunaan aplikasi e-learning sebagai media pembelajaran?

\section{Tujuan Penelitian}

Tujuan penelitian ini adalah untuk mendeskripsikan efektifitas pelaksanaan pembelajaran daring menggunakan e-learning madrasah dan menentukan faktor penghambat dan pendukung penggunaan aplikasi e-learning sebagai media pembelajaran.

\section{KAJIAN TEORI}

Efektifitas bermula dari kata efektif yang bermakna ada efeknya (pengaruhnya, akibatnya, kesannya), mujarab atau manjur dan bisa membawa hasil (Sugono dkk., 2008). Menurut Steers (1985) efektifitas adalah capaian usaha suatu program guna memenuhi sasaran dan tujuan-nya tanpa melemahkan cara dan sumber daya itu serta tanpa adanya tekanan yang tidak wajar pada implementasinya. Menurut Zuhri et al. (2020) dalam pembelajaran dibutuhkan perencanaan yang bagus, penyiapan perangkat pembelajaran, pemilihan media, strategi, model dan teknik pembelajaran, hingga evaluasi yang saling berkesinambungan. Penggunaan modelmodel pembelajaran yang efektif dan inovatif diperlukan agar pembelajaran yang dilakukan dapat lebih berwarna dan berjalan lancar (Zuhri et al., 2020).

Implementasi belajar daring harus tetap memperhatikan tercapainya tujuan pembelajaran. Para ahli merumuskan tujuan pembelajaran yang bervariasi, tetapi seluruhnya kembali pada esensi yang serupa, yaitu: [1] tujuan pembelajaran merupakan tercapainya perubahan perilaku atau kompetensi siswa sesudah menjalani rangkaian aktifitas pembelajaran; [2] tujuan dijabarkan dalam bentuk pernyataan atau deskripsi yang spesifik. Berdasarkan pendangan para ahli terhadap definisi dan tujuan pembelajaran maka dapat disimpulkan bahwa tujuan pembelajaran adalah muara dari seluruh rangkaian aktivitas pembelajaran yang dilaksanakan (Kurniasari, 2020).

Capaian tujuan pembelajaran ditentukan oleh beberapa hal di antaranya adalah: media, proses pembelajaran, dan bahan ajar yang dipilih. Proses pembelajaran merupakan semua upaya bersama yang dilakukan oleh guru dan siswa untuk berbagi dan mengolah informasi. Harapannya pengetahuan yang dibagikan dapat bermanfaat bagi diri siswa dan menjadi dasar belajar yang berkesinambungan. Terjadi perubahan kearah yang lebih baik untuk mencapai peningkatan positif yang ditandai dengan perubahan perilaku individu akan diperoleh dari proses pembelajaran. Kemampuan berpikir kritis dan intelektual akan dibentuk melalui proses pembelajaran (Kurniasari, 2020).

Media pembelajaran juga berkontribusi dalam mencapai tujuan pembelajaran yang ditentukan. Beberapa manfaat media pembelajaran telah diungkapkan para ahli Pendidikan dan pembelajaran diantaranya adalah dapat memicu minat dan keinginan siswa, membangkitkan rangsangan dan motivasi belajar, dan juga memberi efek psikologis kepada siswa. Media dalam kegiatan pembelajaran secara luas mempunyai 
keguanaan untuk memudahkan interaksi antara guru dengan siswa, agar proses pembelajaran dapat berjalan secara lebih efiseien dan efektif (Kurniasari, 2020).

Disamping media dan proses pembelajaran, bahan ajar juga memiliki kontribusi yang sama besarnya untuk mencapai tujuan pembelajaran. Bahan ajar adalah suatu media yang digunakan mencapai keinginan atau tujuan yang akan didapatkan oleh peserta didik. Bahan ajar dapat dimaknai sebagai sesuatu yang memiliki pesan pembelajaran, baik yang bersifat khusus maupun yang bersifat umum yang dapat digunakan untuk keperluan pembelajaran. Bahan ajar seyogyanya didesain mengikuti kaidah pembelajaran, yaitu disesuaikan dengan konten materi pembelajaran, memiliki bahan evaluasi, dibuat atas dasar kebutuhan pembelajaran, dan dapat menarik perhatian siswa. Salah satu alternatif pada komunikasi dalam proses pembelajaran adalah dengan menggunakan bahan ajar sebagai sumber belajar baik secara visual maupun audio visual (Kurniasari, 2020).

Pembelajaran daring merupakan proses pembelajaran yang dilaksanakan oleh guru dan siswa yang tidak dapat bertatap muka secara fisik secara bersama-sama dalam satu tempat yang sama. Proses pembelajaran daring dilaksanakan memanfaatkan bantuan media elektronik berbasis teknologi sehingga kebutuhan belajar siswa dapat terakomodasi dengan baik. Dalam pembelajaran daring siswa dapat melakukan komunikasi yang efektif dengan guru meskipun ada beberapa kendala dan gangguan yang ditemui. Beberapa evaluasi terhadap pembelajaran daring yang dilaksanakan ditemukan berbagai keterbatasan yang ada baik itu dari sisi siswa ataupun dari sisi guru dalam penguasaan aplikasi pembelajaran jarak jauh yang digunakan ataupun juga karena faktor-faktor lain seperti keterbatasan jaringan dan lain sebagainya (Hikmah, 2020).

E-learning merupakan kependekan dari Elektronic Learning. E-learning merupakan inovasi dalam kegiatan pembelajaran yang menggunakan media elektronik khususnya internet sebagai sistem pembelajarannya. E-learning lahir sebagai konsekuensi logis dari perkembangan teknologi informasi dan komunikasi. E-learning Madrasah merupakan aplikasi yang diluncurkan oleh Kementerian Agama Republik Indonesia yang tersedia untuk jenjang Roudlotul Athfal (RA) sampai jenjang Madrasah Aliyah (MA). E-learning dapat dimanfaatkan kapan saja dan dimana saja oleh pengguna (user), selama pengguna memiliki akses internet yang bagus dan mempunyai username dan password untuk membuka aplikasi. E-learning dirancang untuk memberi kemudahan pelaksanaan pembelajaran jarak jauh dalam rangka menjawab tantangan kemajuan Teknologi. E-learning Madrasah merupakan platform pembelajaran yang dibuat oleh Direktorat KSKK Madrasah untuk digunakan oleh guru dan siswa dalam menjalankan pembelajaran jarak jauh, baik pada saat pandemi Covid-19 maupun nanti setelah pandemi berakhir (Hikmah, 2020).

Hingga saat ini, E-learning Madrasah telah menjalani beberapa kali proses pembaruan untuk menambah, mengoptimalkan dan meningkatkan fitur-fitur yang ada. Saat pertama kali dirilis, e-learning muncul dalam versi 1.2.0. Saat ini telah ada versi terbaru yaitu versi 2.0.0 yang sudah dilengkapi dengan fitur Video Conference. Fitur ini memungkinkan guru dan siswa melakukan pembelajaran tatap muka secara daring. Dengan fitur ini, guru dapat berbagi materi pelajaran. Fitur ini menyediakan fasilitas yang memungkinkan terjadi komunikasi dua arah antara guru dan siswa (Hikmah, 2020).

E-learning madrasah memiliki menu yang memungkinkan guru untuk membagi bahan ajar yang akan digunakan dalam kegiatan pembelajaran. Guru dapat membuat kelas sebanyak kelas yang diampu oleh guru tersebut, baik itu guru kelas, guru mata pelajaran, ataupun guru bimbingan konseling. Guru juga dapat membuat kelas online yang menyediakan bukubuku elektronik yang dapat diakses siswa selama 24 jam dari mana pun mereka berada. Sehingga siswa tetap bisa melaksanakan kegiatan literasi dengan baik (Hikmah, 2020).

Guru juga dapat membagikan Rencana Pelaksanaan Pembelajaran, Kompetensi Dasar 
dan Kompetensi Inti setiap pelajaran yang diampu sehingga memberi keleluasaan siswa ataupun bahkan wali murid untuk mengikuti dan memantau pembelajaran yang telah direncanakan (Hikmah, 2020).

E-learning Madrasah juga dilengkapi dengan menu CBT (Computer Based Test) yang memberikan kemudahan siswa mengikuti seluruh rangkaian penilaian pembelajaran mulai kuis, penilaian harian, penilaian akhir semester bahkan penilaian akhir tahun secara online. Beberapa bentuk penilaian disediakan oleh E-learning mulai dari bentuk pilihan ganda, jawaban pendek, essay dan menjodohkan (Hikmah, 2020).

E-learning Madrasah adalah aplikasi yang dibuat Direktorat KSKK Madrasah yang dibagikan secara cuma-cuma yang dirancang untuk mendukung proses pembelajaran di madrasah. Dengan harapan dapat menciptakan pembelajaran yang lebih menarik, terstruktur, dan interaktif. MAN 1 Kota Malang termasuk madrasah yang berada di Kota Malang yang memberikan respon yang cepat dalam menanggapi anjuran pelaksanaan pembelajaran daring menggunakan e-learning madrasah. Gambar 1 menampilkan fitur yang terdapat dalam aplikasi e-learning madrasah.

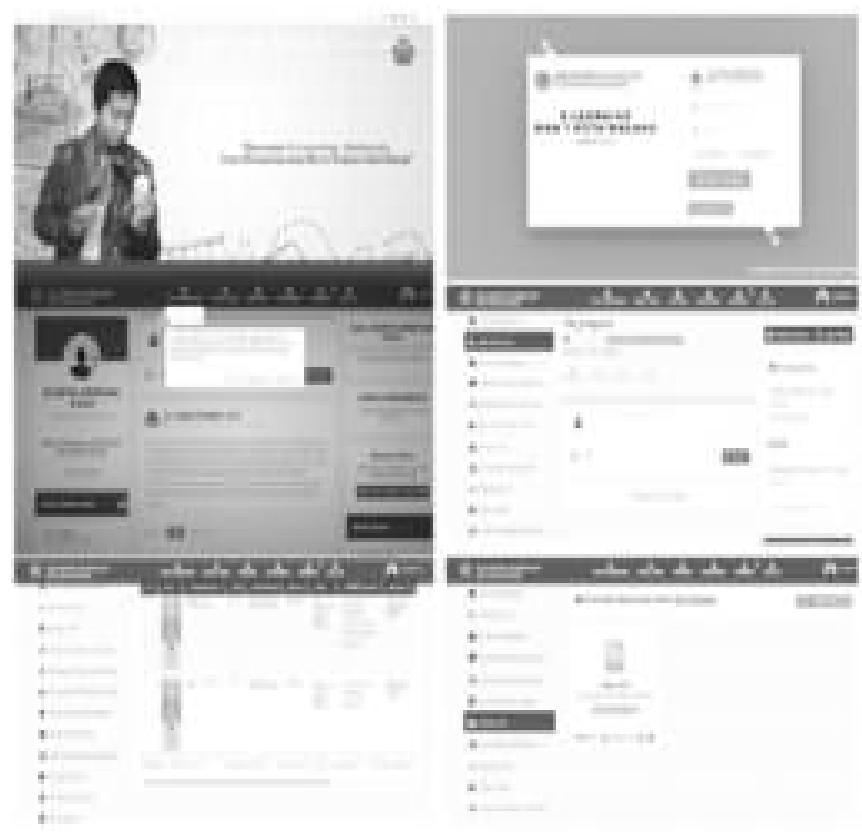

Gambar 1 Tampilan fitur dalam aplikasi e-learning madrasah

\section{METODE PENELITIAN}

Penelitian ini merupakan penelitian deskriptif kualitiatif menggunakan pendekatan survey. Sampel penelitian ini adalah 196 siswa dan 26 guru MAN 1 Kota Malang. Data penelitian diperoleh melalui kuisioner yang disebarkan dalam bentuk google form yang memuat pertanyaan tertutup, semi tertutup dan terbuka. Jawaban dari responden akan dinyatakan dalam persentasi dan selanjutnya ditabulasi dan dianalisis menggunakan statistik deskriptif.

Efektivitas pembelajaran daring menggunakan elearning madrasah diukur dari hasil belajar siswa yang dilihat dari jumlah siswa yang dapat mencapai kriteria ketuntasan minimal (KKM) $\geq 75$.

\section{TEMUAN DAN PEMBAHASAN}

\section{Temuan}

Hasil pengisian angket pelaksanaan pembelajaran daring yang dilakukan oleh guru ditampilkan dalam Gambar 2. Informasi yang diperoleh dari Gambar 2 adalah seluruh guru MAN 1 Kota Malang menggunakan e-learning madrasah dan melakukan penilaian menggunakan e-learning madrasah. Beberapa guru selain menggunakan e-learning madrasah juga menggunakan platform yang lain seperti Google Classroom, Schoology dan Microsoft Teams. Gambar 2 juga menunjukkan $85 \%$ guru menyatakan siswa merespon pembelajaran daring yang dilaksanakan menggunakan e-learning madrasah, dan $73 \%$ guru memanfaatkan fitur video conference dalam pembelajaran daring.

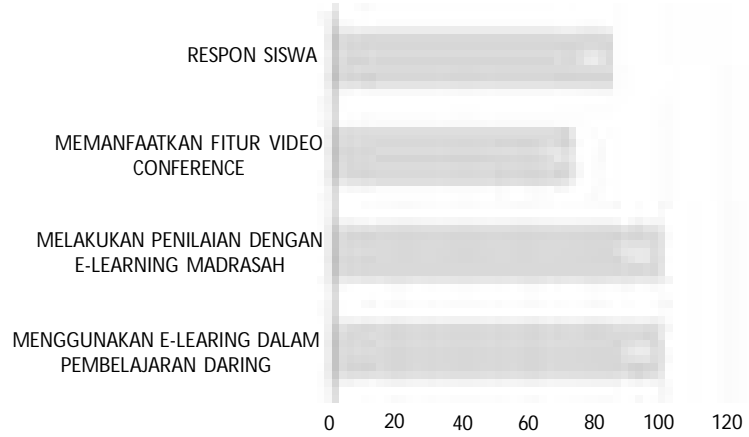

Gambar 2 Hasil Pengisian Angket Pelaksanaan Pembelajaran Daring M enggunakan e-learning Madrasah yang Dilakukan Guru. 
Gambar 3 merupakan hasil pengisian angket yang dilakukan oleh siswa. Sebanyak $80 \%$ siswa menyatakan e-learning madrasah efektif digunakan dalam pembelajaran daring, $80 \%$ siswa menyatakan mudah mengakses e-learning madrasah. Dalam melaksanakan pembelajaran daring, $76 \%$ siswa didampingi oleh orang tua/ wali, $73 \%$ siswa mengerjakan tugas yang diberikan oleh guru, $77 \%$ siswa membaca intruksi yang diberikan guru, dan $78 \%$ siswa dapat mencapai ketuntasan minimal yang telah ditetapkan oleh madrasah.

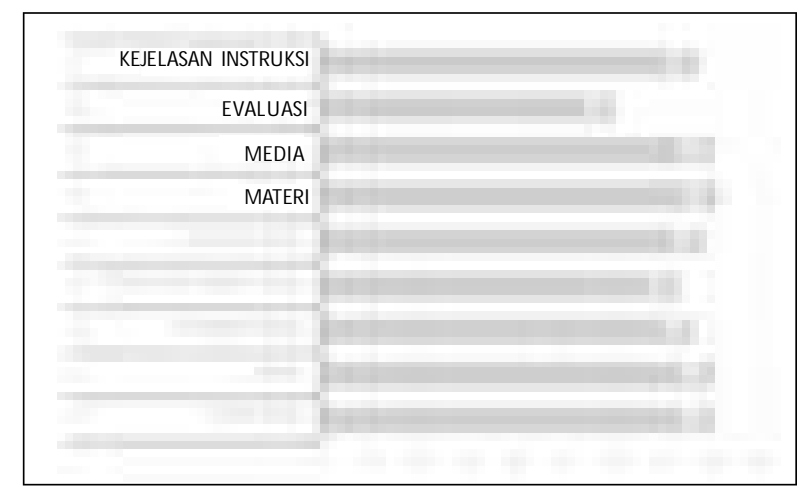

Gambar 3 Hasil Pengisian Angket Pelaksanaan Pembelajaran Daring Menggunakan e-learning Madrasah

Keaktifan siswa dalam pembelajaran daring terlihat dalam Gambar 4. Dari Gambar 4 terlihat bahwa $84 \%$ siswa mengisi presensi pada e-learning madrasah, 78 \% siswa mengikimkan tugas yang diberikan oleh guru dan $86 \%$ siswa mengikuti CBT.

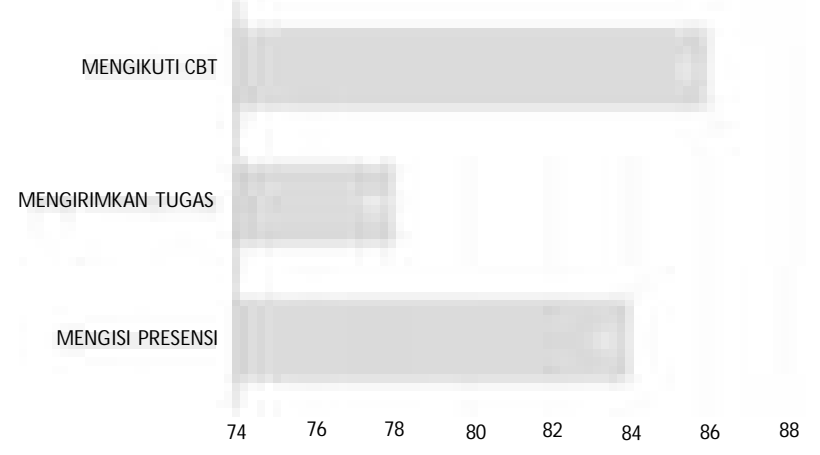

Gambar 4 Keaktifan dan Partisipasi Siswa dalam Pembelajaran Daring M enggunakan e-learning Madrasah

Gambar 5 menampilkan hasil survey mengenai kendala yang dihadapi oleh siswa dalam pembelajaran daring menggunakan e-learning madrasah. Beberapa kendala yang dihadapi oleh siswa antara lain jaringan internet yang tidak stabil, pulsa kuota yang terbatas, tugas yang banyak, tidak dapat memahami materi pelajaran, video tidak dapat diakses, video membosankan dan intruksi guru tidak jelas.

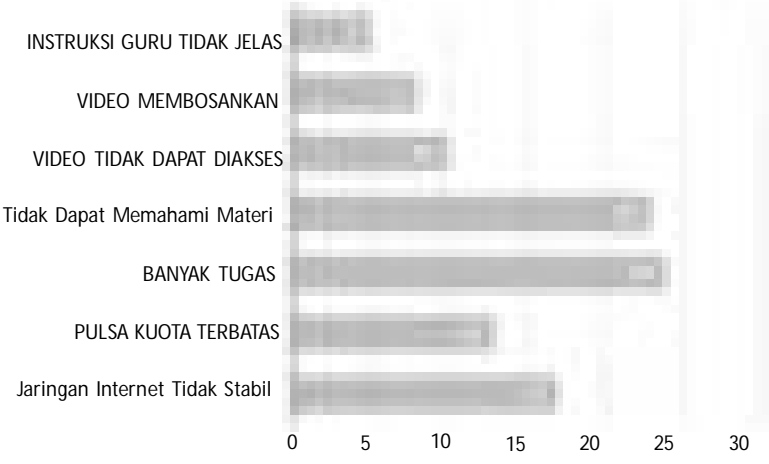

Gambar 5 Kendala yang Dihadapi Siswa dalam Pembelajaran Daring M enggunakan e-learning Madrasah

\section{Pembahasan}

Penggunaan e-learning madrasah oleh seluruh guru MAN 1 Kota Malang dikarenakan sebelum memulai pembelajaran daring, MAN 1 Kota Malang telah mengadakan pelatihan penggunaan e-learning madrasah untuk seluruh civitas akademikanya.

Berdasarkan data yang tersaji dalam Gambar 3 terlihat bahwa siswa menerima kenyataan bahwa saat ini sedang diberlakukan pembatasan sosial dan pembatasan fisik yang menuntut untuk dilakukan pembelajaran dari rumah dan pembelajaran daring. Penggunaan e-learning madrasah sebagai sarana pembelajaran dinilai siswa efektif untuk membantu proses pembelajaran meskipun $10 \%$ siswa menilai biasa saja dan $10 \%$ siswa menilai tidak efektif.

Hasil survey menunjukkan $80 \%$ siswa dapat mengakses pembelajaran daring menggunakan e-learning madrasah secara mandiri tanpa hambatan yang serius. Beberapa hal yang mendukung efektifnya penggunaan e-learning madrasah dalam pembelajaran daring adalah siswa sudah terbiasa melaksanakan pembelajaran dengan bantuan gawai dan laptop sehingga mereka tidak memiliki masalah yang berarti dalam mengakses pembelajaran. Keefektifan penggunaan 
e-learning madrasah dalam pembelajaran daring sesuai dengan pendapat Mustakim (2020) bahwa penggunaan media daring dalam pembelajaran memungkinkan siswa lebih bersemangat untuk belajar dan menyelesaikan tugas (Mustakim, 2020). Penggunaan internet dapat mempengaruhi animo siswa dalam memanfaatkan e-learning madrasah secara signifikan. Hal senada juga disampaikan Hikmah (2020) yang menyatakan terdapat pengaruh positif pemakaian media pembelajaran berbasis internet kepada motivasi belajar siswa (Hikmah, 2020).

Hasil angket menunjukkan $76 \%$ siswa didampingi oleh orang tua dalam proses pembelajaran daring menggunakan e-learning madrasah. Bentuk pendampingan dan dukungan orang tua berupa mengingatkan untuk segera login dan join dalam pembelajaran dan menyediakan sarana dan prasarana untuk mengikuti pembelajaran daring. Bentuk pendampingan orang tua terhadap siswa MAN 1 Kota Malang agak berbeda dengan pendampingan yang dilakukan oleh orang tua siswa level SD/MI karena karakter remaja berbeda dengan anak-anak. Selain itu tidak semua orang tua siswa MAN 1 Kota Malang mampu memberikan penjelasan tentang substansi pelajaran dan tugas yang dibagikan guru. Adanya suport dari wali murid ini menjadi suatu hal yang membuat pembelajaran daring berjalan secara efektif. Peran serta dan keterlibatan orang tua dalam mendampingi putra putrinya melaksanakan pembelajaran daring berimbas positif pada keaktifan siswa dalam pembelajaran daring seperti yang terlihat dalam Gambar 4. Informasi yang dapat diperoleh dari Gambar 4 berupa keaktifan siswa dalam melakukan presensi kehadiran, mengirimkan tugas dan melaksanakan CBT.

Hasil penelitian yang dilaporkan oleh Zuhri (2020) menyebutkan bahwa pemanfaatan e-learning dalam kegiatan pembelajaran terbukti memiliki beberapa keunggulan diantaranya adalah, memberikan kemudahan kepada siswa untuk mengakses materi pembelajaran sesering mungkin tanpa terhalang oleh ruang dan waktu (Zuhri et al., 2020). Hasil penelitian Sabtiawan (2020) mengungkapkan jika model pembelajaran daring membagikan pengetahuan baru yang lebih menarik dibandingkan model pembelajaran normal pada umumnya (Sabtiawan et al., 2020). Pembelajaran daring membebaskan siswa untuk menentukan waktu yang pas untuk belajar sesuai kebutuhan mereka, sehingga kompetensi memahami materi pelajaran diharapkan dapat meningkat.

Hal yang mendukung siswa untuk menikmati pembelajaran daring menggunakan e-learning madrasah adalah adanya media pembelajaran yang disediakan guru dalam pembelajaran daring ini. Video disajikan guru sebagai pelengkap penjelasan yang telah diberikan guru. Hasil survey menunjukkan 80 \% siswa menyimak video yang disediakan oleh guru. Keefektifan video yang digunakan pada pembelajaran merupakan sebagai suplemen guna meningkatkan minat dan perhatian siswa. Hal senada juga disampaikan oleh Astuti (2020) yang mengungkapkan bahwasanya video pembelajaran mempunyai berbagai keunggulan diantaranya adalah video dapat memanipulasi ruang juga waktu, siswa bisa dibawa menjelajah ke manapun meski sedang berada di ruang kelas (Astuti, 2020). Objek pengamatan yang terlalu besar, sangat kecil, rawan membahayakan, atau bahkan tidak bisa didatangi oleh siswa dapat ditampilkan melalui video. Bahkan mata pelajaran yang melatih keterampilan motorik siswa juga dapat memanfaatkan penggunaan video.

Hasil penelitian Huber (2020) menginformasikan bahwa penggunaan e-learning madrasah harus memperhitungkan kaedahkaedah penggunaan serta keunggulan dan kelemahan e-learning agar dapat memacu siswa baik secara intrinsik maupun ekstrinsik, (Huber and Helm, 2020). Pemakaian e-learning madrasah dalam proses pembelajaran harusnya tidak memposisikan siswa hanya sebagai objek, akan tetapi mampu memotivasi peran aktif siswa dalam berdialog, bekerja sama, berinteraksi, berbagi, dan mengkonstruk pengetahuan secara bersama. Tidak hanya itu, dalam pembelajaran mengaplikasikan e-learning guru harus profesional, inovatif kritis dan kreatif dalam menentukan bahan pelajaran, pemakaian audio atau gambar yang tidak bersesuaian dengan 
materi pembelajaran hendaknya dihindari, beretika baik dalam memanfaatkan bahan tersebut, memberikan atensi dan meluangkan waktu yang cukup kepada siswa tak terbatas pada waktu tatap muka di kelas, mendorong partisipasi aktif dari siswa, sabar membimbing siswa yang menemui kendala dalam menggunakan e-learning, dan mempunyai kemauan untuk terus belajar dan meningkatkan kompetensinya.

Temuan Hikmat (2020) memperlihatkan bahwa pembelajaran dapat berlangsung secara efektif apabila terdapat interaksi antara guru, sumber belajar dan siswa. Guru harus mengorganisir pembelajaran agar siswa turut berperan aktif dalam sistem pembelajaran. Hasil kajian Kamsurya (2020) menunjukkan bahwa guru dan siswa dapat melakukan interaksi secara langsung melalui metode diskusi/forum, sehingga memberi kemudahan siswa dalam proses pembelajaran (Kamsurya, 2020).

Pembelajaran daring dengan memanfaatkan e-learning madrasah ini cukup baru di kalangan guru dan siswa di madrasah, sehingga tidak heran jika ada responden yang menyatakan pembelajaran secara daring menggunakan e-learning madrasah biasa saja dan ada yang menyatakan tidak efektif. Menurut Kuleva (2020) ada tiga respon perilaku seseorang saat menemui hal baru, pada mulanya dia akan menolak kenyataan, lalu dia akan bernegosiasi, dan selanjutnya dia akan menerima (Kuleva, 2020). Saat ini mungkin siswa menganggap pembelajaran daring menggunakan e-learning madrasah tidak efektif disebabkan mereka masih pada tahap menolak yang itu dikarenakan pembelajaran daring menggunakan e-learning madrasah ini baru berlangsung. Ada kemungkinan beberapa saat ke depan ketika siswa dikemukakan lagi hal yang sama, maka respon mereka akan berbeda karena mereka telah mampu beradaptasi menggunakan e-learning madrasah.

Selain alasan masih belum terbiasa menggunakan aplikasi e-learning madrasah, ada beberapa kendala yang dihadapi siswa dalam pembelajaran daring menggunakan e-learning madrasah. Gambar 5 menampilkan hasil survey mengenai kendala yang dihadapi oleh siswa dalam pembelajaran daring menggunakan e-learning madrasah.

Tidak dapat dipungkiri bahwa kesiapan akses internet dibutuhkan pada pembelajaran daring menggunakan e-learning madrasah. Hal tersebut disebabkan ciri khas pembelajaran ini selalu memerlukan jaringan internet. Diakui oleh umum, kualitas akses internet di Indonesia kurang bagus, jangkauan jaringan internet yang belum merata dan biaya yang tidak murah menjadi hambatan bagi pembelajaran e-learning. Upaya yang bisa ditempuh untuk mengatasi hambatan ini, maka madrasah dapat menyediakan subsidi kepada siswa, yang dapat berasal dari dana BOS, atau dari dana sosial. (Khusniyah dan Hakim, 2019).

Beragam unsur yang diketahui sebagai pemicu ketidakefektifan pembelajaran dari rumah adalah adanya rintangan saat proses belajar sedang berjalan antara lain gawai, TV dan game yang menyebabkan siswa tidak konsentrasi saat menjalani proses evaluasi pembelajaran. Ada kecenderungan siswa untuk segera menyudahi kegiatan pembelajaran. Kurang efektifnya komunikasi antara siswa dengan siswa lainnya serta antara guru dengan siswa memicu pelaksanaan belajar dari rumah semakin lama semakin membosankan bagi siswa. Faktor lain yang dapat menghambat efektifitas proses belajar dari rumah adalah rumitnya aplikasi yang tidak biasa dipakai siswa, baik siswa maupun guru tidak familier dengan media pembelajaran daring yang digunakan.

Efektivitas pembelajaran daring menggunakan e-learning madrasah juga dipengaruhi oleh kemampuan guru. Adanya tiga kendala yang dihadapi siswa selama pembelajaran daring menggunakan e-learning madrasah yaitu video membosankan, materi susah dipahami dan intruksi guru tidak jelas menunjukkan adanya kelemahan guru dalam mengelola pembelajaran. Setidaknya ada tiga manajemen yang harus dikuasai guru ketika mengorganisir pembelajaran daring, yaitu manajemen kelas, pembelajaran dan waktu (Rahmawati et al., 2020).

Pelaksanaan pembelajaran daring yang efektif akan dapat diselenggarakan oleh guru dengan visi yang jelas serta dapat merajut kedekatan emosional dengan siswa melalui mengoptimalkan perannya sebagai fasilitator, mediator, komunikator, 
dan motivator. Pembelajaran daring akan berjalan secara tidak efektif karena dipicu keterbatasan dalam berinteraksi, berkomunikasi, dan berinovasi, baik dikarenakan jaringan akses internet maupun gangguan yang lainnya, akibatnya guru dan siswa hendaklah dapat menyesuaikan diri dengan hal-hal baru (Nuriansyah, 2020). Peran istimewa juga dimiliki guru untuk membuat siswa bermental juara dengan cara memotivasi mereka agar giat belajar dan disiplin dalam menyelesaikan tugas yang menjadi tanggung jawabnya. Pembelajaran daring akan disebut efektif apabila semua siswa terlibat secara aktif dalam pembelajaran pada saat berinteraksi dengan guru, antusias berkomunikasi dan presentasi, serta dapat memaksimalkan pemanfaatan berbagai sumber dan media belajar. Guru dituntut inovatif dalam menyampaikan materi, mendesain tugas yang dapat mendorong siswa untuk berfikir kritis dan bertanya baik kepada teman, guru, maupun orang tua mereka, serta memiliki metode mengajar yang menyenang kan. Kemampuan mengajar dan mengorganisir kelas hendaknya dikuasai oleh guru, sehingga bisa menstimulasi dan memicu minat siswa dalam mengikuti kegiatan pembelajaran (Kusuma and Hamidah, 2020).

Diantara sembilan indikator yang diamati, evaluasi mendapatkan nilai yang paling kecil bila dibandingkan dengan indikator yang lain. Siswa merasa tugas yang diberikan terlalu membebani. Pada pelaksanaan pembelajaran dari rumah ada beberapa materi yang disampaikan melalui lembar kerja siswa (LKS). Hal ini dilakukan agar dapat menstimulasi kemandirian siswa saat belajar dan kemampuan berpikir kritisnya. Akan tetapi hal ini ditanggapi siswa sebagai beban yang memberatkan. Pada dasarnya tugas yang diberikan guru merupakan suatu proses yang sengaja didesain oleh guru untuk menilai proses pembelajaran, tidak hanya untuk menilai capaian akhir saja. Fenomena ini menunjukkan adanya beda persepsi antara guru dan siswa terhadap proses evaluasi.

Perbedaan persepsi itu muncul disebabkan minimnya komunikasi efektif antara siswa dan guru. Dalam pembelajaran yang dilakukan dengan sistem asinkronus, siswa cenderung pasif dalam merespon arahan yang diberikan guru. Demikian pula saat pembelajaran secara sinkron dilaksanakan, pada umumnya yang aktif berbicara hanya guru. Siswa kurang percaya diri menyampaikan gagasannya secara terbuka melalui video conference yang dilakukan saat pembelajaran secara sinkron.

Kendala yang dihadapi dalam pembelajaran daring menggunakan e-learning madrasah dapat diatasi dengan cara penyampaian materi pembelajaran seyogyanya dilakukan secara ringkas, untuk menghemat kuota sebaiknya meminimalisir memberi materi dalam bentuk video berdurasi lama, membuat video dengan pemakaian bahasa yang mudah dimengerti, selalu menyampaikan materi terlebih dahulu sebelum memberikan tugas, pemberian tugas tidak terlalu berlebihan dan soal harusnya lebih bervariasi, serta penyampaian tugas disertai dengan instruksi yang jelas.

\section{PENUTUP}

\section{A. Simpulan}

Berdasarkan pada hasil survey dan uraian analisis dapat ditarik kesimpulan bahwa inovasi pembelajaran daring menggunakan e-learning madrasah membantu siswa menjalani pembelajaran selama masa pandemi. Pelaksanaan pembelajaran daring menggunakan e-learning madrasah berlangsung cukup efektif yang terlihat dari $78 \%$ siswa dapat mencapai kriteria ketuntasan minimal (KKM). Beberapa hal yang mendukung penggunaan aplikasi e-learning adalah: 1] siswa telah terbiasa melaksanakan pembelajaran dengan bantuan gawai dan laptop, 2] adanya pendampingan dan dukungan orang tua dalam pembelajaran, 3] adanya media pembelajaran yang berupa video yang disediakan guru dalam pembelajaran daring, 4] adanya interaksi antara siswa dan guru. Faktor-faktor yang menghambat penggunaan e-learning madrasah adalah: 1] Guru dan siswa belum ter biasa menggunakan aplikasi e-learning madrasah, 2] akses internet yang kurang bagus, 3] komunikasi guru dan siswa kurang efektif dan 4] aplikasi yang rumit. Profesionalitas guru sangat dibutuhkan dalam pembelajaran daring 
menggunakan e-learning madrasah untuk membuat pembelajaran yang menyenangkan dan bermakna. Penyempurnaan aplikasi juga masih diperlukan agar e-learning madrasah lebih mudah dipergunakan (user-friendly). Kendala yang dihadapi dalam pembelajaran daring dapat diatasi dengan adanya kerjasama antara madrasah, orang tua, guru dan siswa.

\section{B. Rekomendasi}

Rekomendasi yang dapat diberikan melalui penelitian ini adalah : [1] kehadiran aplikasi elearning madrasah ini sudah selayaknya diapresiasi oleh seluruh madrasah dengan dijadikan sebagai media pembelajaran, [2] terwujudnya aplikasi e-learning madrasah dapat digunakan sebagai bukti bahwa madrasah mampu berinovasi, [3] diperlukan adanya sinergi dari seluruh pihak untuk semakin melangkapi dan menyempurnakan aplikasi e-learning madrasah.

\section{DAFTAR PUSTAKA}

Astuti, A. dan Dewi. D.P. , 2020. Efektivitas Penggunaan Media Belajar Dengan Sistem Daring Ditengah Pandemi Covid-19. Web-Seminar Nasional, (January), pp. 129-135.

Fitrah, M. dan Ruslan, 2021. Eksplorasi Sistem Pelaksanaan Evaluasi Pembelajaran di Sekolah pada Masa Pandemi Covid-19 di Bima. Jurnal Basicedu, 5(1), pp. 178- 187.

Hikmah, S., 2020. Pemanfaatan e-learning Madrasah dalam Pelaksanaan Pembelajaran JarakJ auh Masa Pandemi di MIN 1 Rembang. Edutrained: Jurnal Pendidikan dan Pelatihan, 4(2), pp.73-85.

Hikmat, Hermawan, E. A Aldim dan Irwandi, 2020. Efektivitas Pembalajaran Daring Selama Masa Pandemi Covid19/ : Sebuah Survey Online. Digital Library, UIN Sunan Gunung Djati, Bandung, pp. 1-7.

Huber, S.G and Helm, C., 2020. COVID-19 and schooling: evaluation, assessment and accountability in times of crises- reacting quickly to explore key issues for policy, practice and research with the school barometer. Educational Assessment, Evaluation and Accountability, 32(2), pp. 237-270.

Kamsurya, R., 2020. Learning Evaluation of Mathematics during the Pandemic Period COVID-19 in Jakarta. International Journal of Pedagogical Development and Lifelong Learning, 1(2), p.ep2008.

Khusniyah, H. , 2020. Pembelajaran yang Dipaksa Pulang. Ampel Denta, 7(1), pp. 31-33.

Khusniyah, N. L. dan Hakim, L., 2019. Efektivitas Pembelajaran Berbasis Daring: Sebuah Bukti Pada Pembelajaran Bahasa Inggris. Jurnal Tatsqif, 17(1), pp.19-33.

Kuleva, M., 2020. the Impact of Covid-19 Pandemic on the Evaluation of the Effectiveness of Online Distance Learning. Pedagogika-Pedagogy, 92(7, S), pp.74-83.

Kurniasari, A., Pribowo, F. S. P., dan Putra, D. A., 2020. Analisis Efektivitas Pelaksanaan Belajar Dari Rumah (BDR) Selama Pandemi Covid-19. Jurnal Review Pendidikan Dasar: Jurnal Kajian Pendidikan dan Hasil Penelitian, 6(3), pp.1-8.

Kusuma, J.W. dan Hamidah, H., 2020. Perbandingan Hasil Belajar Matematika Dengan Penggunaan Platform Whatsapp Group Dan Webinar Zoom Dalam Pembelajaran Jarak Jauh Pada Masa Pandemik Covid 19. JIPMat, $5(1)$.

Mustakim, 2020. Efektivitas Pembelajaran Daring Menggunakan Media Online Selama Pandemi Covid-19 Pada Mata Pelajaran Matematika the Effectiveness of E-learning Using Online Media During the Covid-19 Pandemic in Mathematics. Al asma: Journal of Islamic Education, 2(1), pp. 1-12.

Nuriansyah, F. , 2020. Efektifitas Penggunaan Media Online Dalam Meningkatkan Hasil Belajar Pada Mahasiswa Pendidikan Ekonomi Saat Awal Pandemi Covid-19. Jurnal Pendididikan Ekonomi Indonesia, 1(2), pp.6165.

Oktavian, R. dan Aldya, R.F., 2020. Efektivitas Pembelajaran Daring Terintegrasi di Era Pendidikan 4.0. Didaktis: Jurnal Pendidikan dan IImu Pengetahuan, 20(2), pp.129-135.

Rahmawati, N.R., Rosida, F.E. dan Kholidin, F.I., 2020. Analisis Pembelajaran Daring Saat Pandemi Di Madrasah Ibtidaiyah. SITTAH: J ournal of Primary Education, 1(2), pp.139-148. 
Sabtiawan, W. B., Sudibyo, E. , Yonata, B., Putri, N.P., Trimulyono, G and Savitri, D. , 2020. Online Teaching in Mathematics and Natural Sciences Faculty, Universitas Negeri Surabaya in Early Pandemic of Covid-19/ : Preparation, Implementation, and Assessment. Jurnal Penelitian Pendidikan IPA, 5(1), pp.15- 18.

Steers, R., 1985. Managing Efective Organization. Boston. Kent Pulb Comb. Pp.1-87.

Sugono, D., Sugiyono, Maryani, Y., Qodratillah, M.T., 2008. Kamus Besar Bahasa Indonesia. Pusat Bahasa Departemen Pendidikan Nasional. Jakarta, pp.1-1490.

Zuhri, M.T., Agung, B. dan Ramdhani, K., 2020. Effectiveness Of The Use Of Madras E-learning Applications During The Covid Pandemic 19 (Case Study at Madrasah Aliyah Negeri 2 Bandung). At-Ta'dib, 15(1), pp. 138-155. 